\title{
PELAYANAN DAN ASISTENSI PENGISIAN SPT WAJIB PAJAK ORANG PRIBADI DI SEKITAR KAMPUS UNTAR
}

\author{
Dieni Indrajati $\mathbf{W}^{1}$, Estralita $\mathbf{T}^{2}$ \\ ${ }^{1}$ Jurusan Akuntansi, UniversitasTarumanagara Jakarta \\ Email: djenii@fe.untar.ac.id \\ ${ }^{2}$ Jurusan Akuntansi, UniversitasTarumanagara Jakarta \\ Email: estralitat@fe.untar.ac.id
}

\begin{abstract}
In recent years, the Directorate General of Taxes has been very intensive in providing services in the form of counseling to taxpayers. They make various work programs to provide tax awareness inclusion by involving the participation of the world of education from elementary school to university levels. One of the activities in question is forming Tax Volunteers from interested students. Tarumanagara University in this case driven by the Faculty of Economics and Business received an invitation to also be involved and the invitation was welcomed by several lecturers and became a Community Service Activity (PKM) which is one of the manifestations of the Tri Dharma of Higher Education. This activity provides benefits to the community in this case to taxpayers who work or have businesses around the Untar Campus, including Untar lecturers and employees who will fulfill their tax obligations. These activities include consultation and assistance, helping to calculate and determine the amount of income tax payments that must be fulfilled by taxpayers along with filling out and reporting annual tax returns. The benefit for Tarumanagara University-especially the Faculty of Economics is the role of supporting the Government, especially in the inclusion of tax awareness. This is being promoted and programmed by the Directorate General of Taxes and at the same time to further foster relationships with the surrounding community.
\end{abstract}

Keywords: Services and Assistance, Directorate General of Taxes and Office Tax Services, Tax Volunteers, Individual Taxpayers, Annual SPT.

\begin{abstract}
ABSTRAK
Dalam beberapa tahun terakhir ini, pihak Direktorat Jenderal Pajak sangat intensif memberikan pelayanan berupa penyuluhan kepada para wajib pajak. DJP membuat berbagai program kerja untuk memberikan inklusi kesadaran pajak dengan melibatkan peran serta dunia pendidikan mulai dari tingkat Sekolah dasar sampai dengan Universitas. Salah satu kegiatan yang dimaksud adalah membentuk Relawan Pajak dari para mahasiswa yang berminat Universitas Tarumanagara dalam hal ini dimotori oleh Fakultas Ekonomi dan Bisnis mendapat undangan untuk juga terlibat dan undangan tersebut disambut baik oleh beberapa dosen dan menjadi Kegiatan Pengabdian Kepada Masyarakat (PKM) yang adalah salah satu perwujudan Tri Dharma Perguruan Tinggi. Kegiatan ini memberikan manfaat kepada masyarakat yaitu kepada para wajib pajak yang bekerja atau mempunyai usaha disekitar Kampus Untar termasuk juga untuk para dosen dan karyawan Untar yang akan memenuhi kewajiban perpajakannya. Kegiatan tersebut antara lain berupa konsultasi dan asistensi, membantu menghitung dan menentukan jumlah setoran pajak penghasilan yang harus dipenuhi para wajib pajak beserta pengisian dan pelaporan SPT tahunannya. Manfaat bagi Universitas Tarumanagara-khususnya Fakultas Ekonomi merupakan peran serta mendukung Pemerintah khususnya dalam inklusi kesadaran perpajakan. Hal mana sedang digiatkan dan diprogramkan pihak Direktorat Jenderal Pajak dan sekaligus untuk lebih membina hubungan dengan masyarakat sekitar.
\end{abstract}

Kata Kunci: Pelayanan dan Asistensi , Direktorat Jenderal Pajak dan Kantor Pelayanan Pajak, Relawan Pajak, Wajib Pajak Orang Pribadi, SPT Tahunan.

\section{PENDAHULUAN}

Kegiatan Relawan Pajak yang dilakukan oleh Direktorat Jenderal Pajak yang melibatkan mahasiswa telah berlangsung selama beberapa tahun. Sejak tahun 2017, dengan terbitnya Peraturan Direktur Jenderal Pajak Nomor PER-03/PJ/2014 Tentang Penyampaian Surat Pemberitahuan Eletronik dilakukan perekrutan Relawan Pajak dari berbagai Perguruan Tinggi. Peraturan ini mengharuskan Wajib Pajak menggunakan komputer/ saluran online 
dalam melaporkan SPT bagi wajib pajak orang pribadi (WP OP). Untuk mengantisipati banyaknya WP OP yang membutuhkan asistensi pelaporan SPT menggunakan e-filing, maka Dirjen pajak membentuk Team Relawan Pajak (RP) yang melibatkan mahasiswa untuk membantu WP OP dalam memenuhi kewajiban pajaknya, yaitu ,melaporkan pajak penghasilannya dengan menggunakan e-filing. Kegiatan Relawan Pajak dalam membantu WPOP dalam melaporkan SPT mereka dengan e-filing berjalan sampai tahun 2020 sebelum Pandemi Covid19 meluas maka kegiatan ini dihentikan pada tanggal 15 Maret 2020.

Disisi lain, tax ratio tahun 2018 sebesar 11.5\%, dan di tahun 2019 turun menjadi 10.7 \%, Tax Ratio yaitu perbandingan penerimaan pajak terhadap produk domestik bruto. Rasio ini merupakan alat ukur untuk menilai kinerja penerimaan pajak suatu Negara. Untuk mengatasi masalah tersebut, maka Pemerintah khususnya Direktorat Jenderal Pajak (DJP) membutuhkan peran aktif dari Perguruan Tinggi yang peduli terhadap nasib bangsa dan negara Indonesia. Perguruan Tinggi diharapkan dapat membantu DJP dalam berkontribusi dengan memberikan pengetahuan dan menyampaikan kesadaran perpajakan kepada masyarakat untuk membayar pajak. Salah satu program kerja Direktorat Jenderal Pajak adalah membentuk Relawan Pajak yang berasal dari beberapa Perguruan Tinggi terpilih. Relawan Pajak selain berkontribusi kepada negara, juga sebagai pengembangan kapasitas diri dan networking adalah manfaat yang dapat diperoleh oleh mahasiswa/i sebagai Relawan Pajak. Tidak bisa dipungkiri bahwa pengalaman di lapangan akan menjadi bekal untuk memasuki dunia kerja yang makin kompetitif. Relawan Pajak nantinya tentu akan lebih unggul mendalami hal-hal ekonomi terutama dalam bidang perpajakan. Di lain sisi, kegiatan ini juga sebagai wadah bagi dosen dan kampus untuk melaksanakan pengabdian kepada masyarakat sebagai salah satu pilar tridarma perguruaan tinggi.

Pajak adalah iuran rakyat kepada kas negara berdasarkan undang-undang (yang dapat dipaksakan) dengan tidak mendapat jasa timbal balik (kontraprestasi) yang langsung dapat ditunjukkan dan yang digunakan untuk membayar pengeluaran umum (Resmi, 2018:1). Berdasarkan pengertian pajak tersebut, rakyat diwajibkan untuk membayar pajak kepada pemerintah guna pengeluaran umum. Oleh karena itu, fungsi pajak menurut Waluyo (2011:6) yaitu fungsi budgetair (sumber keuangan negara), pajak berfungsi sebagai sumber dana yang diperuntukkan bagi pembiayaan pengeluaran-pengeluaran pemerintah; dan fungsi regulated (pengatur), pajak berfungsi sebagai alat untuk mengatur atau melaksanakan kebijakan sosial dan ekonomi. Selain itu, juga mencapai tujuan-tujuan tertentu di luar bidang keuangan.

Setiap orang pribadi yang berpenghasilan merupakan Wajib Pajak. Wajib Pajak berdasarkan Undang-Undang No. 28 Tahun 2007 adalah orang pribadi atau badan yang meliputi pembayar pajak, pemotong pajak, dan pemungut pajak, yang mempunyai hak dan kewajiban perpajakan sesuai dengan ketentuan perundang-undangan perpajakan (RI, 2008). Hal ini membuat Wajib Pajak harus mengerti akan kewajiban dan hak Wajib Pajak yang dimilikinya Menurut Susyanti dan Dahlan (2015:51), Pajak Penghasilan (PPh) dikenakan terhadap orang pribadi dan badan, berkenaan dengan penghasilan yang diterima atau diperoleh selama satu tahun pajak. Subjek PPh meliputi: orang pribadi; warisan yang belum terbagi sebagai satu kesatuan, menggantikan yang berhak; badan; dan bentuk usaha tetap (BUT). Menghitung pajak penghasilan merupakan kewajiban dari Wajib Pajak Orang Pribadi. Pajak Penghasilan dapat dipungut dengan self assessment system, official assessment system, dan withholding system (Resmi, 2018:124). Dengan self assessment system, Wajib Pajak menghitung sendiri pajak penghasilan yang terutang, menyetor, dan melaporkannya dalam suatu tahun dengan mengisi surat pemberitahuan (SPT) Tahunan Wajib Pajak (orang pribadi atau badan). Dalam hal terdapat penghasilan yang telah dipotong pajaknya oleh pihak lain, pada akhir tahun pajak, seluruh penghasilan tersebut diperhitungkan kembali untuk menentukan PPh terutang. 
Pajak-pajak yang telah dipotong oleh pihak lain tersebut sepanjang bersifat tidak final, dapat dikreditkan terhadap PPh yang terutang.

Penghitungan pajak oleh Wajib Pajak Orang Pribadi biasanya dengan cara PPh Terutang sama dengan Tarif Pajak dikalikan Penghasilan Kena Pajak. Menurut Resmi (2018:125) Tarif pajak merupakan persentase tertentu yang digunakan untuk menghitung besarnya $\mathrm{PPh}$. Tarif PPh yang berlaku di Indonesia dikelompokkan menjadi dua, yaitu tarif umum dan tarif khusus. Tarif umum diatur dalam Pasal 17 Undang-Undang PPh yang terutang dalam UU No. 7 Tahun 1983 sebagaimana telah diubah beberapa kali dan terakhir adalah dalam UU No. 36 Tahun 2008, dan tarif khusus yaitu tarif pajak ini mengikuti tarif pajak yang ditetapkan dengan Peraturan Pemerintah biasanya ditujukan pada penghasilan tertentu, misalnya bunga deposito yang diikuti pula dengan pengenaannya yang bersifat final (Sudirman dan Amiruddin, 2015:82).

Sistem penerapan tarif Pajak Penghasilan sesuai dengan Pasal 17 UU PPh dibagi menjadi dua, yaitu Wajib Pajak orang pribadi dalam negeri, dan Wajib Pajak dalam negeri badan dan bentuk usaha tetap. Sistem penerapan tarif Pajak Penghasilan yang akan dibahas adalah sistem penerapan tarif pajak untuk Wajib Pajak Orang Pribadi dalam negeri yaitu:

1. Tarif PPh untuk Wajib Pajak Orang Pribadi dalam negeri (pasal 17 ayat (1) huruf a UU $\mathrm{PPh})$ yaitu $5 \%, 15 \%, 25 \%$ dan $30 \%$.

2. Tarif khusus PPh terutang sebesar $0,5 \%$ dari peredaran bruto usaha bagi Wajib Pajak orang pribadi dan badan kecuali bentuk usaha tetap yang memiliki penghasilan peredaran bruto usaha tertentu. Peredaran bruto usaha tertentu yang dimaksud adalah sebesar Rp. 4.800.000.000 (empat koma delapan miliar rupiah) setahun. Ketentuan ini diatur dalam Peraturan Pemerintah Nomor 23 Tahun 2018. Setelah pajak terutang dihitung, maka Wajib Pajak Orang Pribadi mengisi Surat Pemberitahuan (SPT) (Resmi, 2018:42) yang merupakan sarana bagi Wajib Pajak untuk melaporkan hal-hal yang berkaitan dengan kewajiban perpajakan. SPT harus diisi dengan benar, lengkap, dan jelas dalam bahasa Indonesia dengan menggunakan huruf latin dan angka arab, satuan mata uang rupiah dan menandatangani serta menyampaikannya ke Kantor Pelayanan Pajak (KPP) atau tempat lain yang ditetapkan oleh Direktur Jenderal Pajak.

Fungsi SPT bagi Wajib Pajak Pajak Penghasilan (Resmi, 2018:42) adalah sebagai sarana untuk melaporkan dan mempertanggungjawabkan penghitungan jumlah pajak yang sebenarnya terutang dan untuk melaporkan tentang:

1. Pembayaran atau pelunasan pajak yang telah dilaksanakan sendiri dan/atau melalui pemotongan atau pemungutan pihak lain dalam 1 (satu) Tahun Pajak atau Bagian Tahun Pajak;

2. Penghasilan yang merupakan Objek Pajak dan/atau buka Objek Pajak;

3. Harta dan kewajiban; dan/atau

4. Pembayaran dari pemotong atau pemungut tentang pemotongan atau pemungutan pajak orang pribadi atau badan lain dalam 1 (satu) Masa Pajak sesuai dengan ketentuan peraturan perundang-undangan perpajakan yang berlaku.

Surat Pemberitahuan (SPT) Tahunan, yaitu SPT yang digunakan untuk pelaporan tahunan. SPT Tahunan yang digunakan oleh Wajib Pajak Orang Pribadi terdiri atas:

a. SPT Tahunan PPh Wajib Pajak Orang Pribadi yang mempunyai penghasilan dari usaha/pekerjaan bebas yang menyelenggarakan pembukuan atau norma penghitungan penghasilan neto; dari satu atau lebih pemberi kerja; yang dikenakan $\mathrm{PPh}$ final dan/atau bersifat final; dan dari penghasilan lain (1770).

b. SPT Tahunan PPh Wajib Pajak Orang Pribadi yang mempunyai penghasilan dari satu atau lebih pemberi kerja; dalam negeri lainnya; dan yang dikenakan $\mathrm{PPh}$ final dan/atau bersifat final (1770S); 
c. SPT Tahunan PPh Wajib Pajak Orang Pribadi yang mempunyai penghasilan dari satu pemberi kerja dan tidak mempunyai penghasilan lainnya kecuali bunga bank dan/atau bunga koperasi (1770SS).

Berdasarkan peran Wajib Pajak Orang Pribadi yang dipaparkan di atas, Wajib Pajak Orang Pribadi juga perlu memiliki pengetahuan yang cukup mengenai perhitungan, pembayaran, pengisian SPT Tahunan Wajib Pajak Orang Pribadi, dan pelaporan atas pajak dalam bentuk SPT Tahunan Wajib Pajak Orang Pribadi.

\section{Kondisi mitra}

Pada setiap tahun terutama pada masa masa pelaporan pajak orang pribadi yang berakhir di tanggal 31 Maret tahun berikutnya, tingkat kesibukan dan kepadatan kerja petugas Kantor Pelayanan Pajak sangat tinggi. Disatu pihak ada kesadaran dari para wajib pajak untuk memenuhi kewajiban perpajakannya yaitu melapor SPT, dipihak lain masih banyak yang menunggu sampai ke waktu yang hampir berakhir. Akibatnya petugas KPP kewalahan, wajib pajak juga tidak sabar dan kecewa.

Menyadari berbagai kendala diatas, Kementerian Keuangan, khususnya DJP dan KPP telah berbenah diri antara lain dengan bantuan teknologi (e-filling dan lain lain) dan mengedukasi masyarakat melalui program Inklusi Kesadaran Pajak, yang salah satu programnya adalah merekrut mahasiswa melalui perguruan tinggi terpilih untuk menjadi Relawan Pajak. Pada masa masa pelaporan SPT Tahunan Orang Pribadi inilah para Relawan Pajak berperan membantu petugas KPP melayani para wajib pajak. Kebutuhan tersebut ditanggapi oleh beberapa dosen tetap FE Untar yang memiliki keahlian dibidangnya untuk membimbing dan mensupervisi kegiatan Relawan Pajak.

\section{Uraian hasil penelitian dan PKM terkait}

Dalam penelitian yang dilakukan Lukman, dkk (2020) yang meneliti minat mahasiswa untuk menjadi Relawan Pajak, ditemui signifikansi minat responden (mahasiswa Relawan Pajak) untuk menjadi Relawan Pajak. Hal itu mendorong pihak FEB Untar khususnya kami untuk mengadakan lagi penyuluhan/konsultasi dan bantuan pengisian dan pelaporan SPT Tahunan bagi wajib Pajak Orang Pribadi.

\section{METODE PELAKSANAAN PKM}

Kegiatan ini telah dilakukan pada tanggal 17-19 Maret dan 26 Maret 2021 di Kampus I Untar. Seleksi dan Pelatihan kepada mahasiswa Relawan pajak dilakukan pada bulan Januari dan Februari 2021. Sedangkan pada Februari Minggu ke 1 dan ke 2 dilakukan Rapat dan persiapan dengan pihak DJP dan KPP secara daring.

Pada minggu ke 3 bulan Maret 2021, dimulainya Pelaksanaan kegiatan secara luring dengan supervisi dari tim dosen. 
Jadwal kegiatan ini secara keseluruhan adalah sebagai berikut:

Tabel 1. Jadwal kegiatan

\begin{tabular}{|c|c|c|c|c|c|c|}
\hline \multirow{2}{*}{ No } & \multirow{2}{*}{ Jenis Kegiatan } & \multicolumn{5}{|c|}{ Minggu / Bulan (sesuaikan dengan kegiatan) } \\
\hline & & 1 & 2 & 3 & 4 & 5 \\
\hline 1 & Kegiatan Rapat dan Koordinasi & $\begin{array}{l}\text { Jan } \\
2021\end{array}$ & & & & \\
\hline 2 & $\begin{array}{lcc}\text { Kegiatan } & \text { Seleksi dan } & \text { Pelatihan } \\
\text { menjadi } & \text { mahasiswa } & \text { Relawan } \\
\text { Pajak } & & \end{array}$ & $\begin{array}{l}\text { Feb } \\
2021\end{array}$ & $\begin{array}{l}\text { Feb } \\
2021\end{array}$ & & & \\
\hline 3 & Pelaksanaan & & & & & \\
\hline 4 & Penyelesaian & & & & $\begin{array}{l}\text { Juni } \\
2021\end{array}$ & \\
\hline
\end{tabular}

Pelaksanaan kegiatan ini dalam bentuk luring dan diadakan di lantai 8, Gedung blok M Kampus UNTAR 1, didahului penyebaran informasi acara melalui media sosial dan pendaftaran melalui google form.

\section{TAHAPAN KEGIATAN}

Adapun tahapan kegiatan adalah sebagai berikut : (1) Tahap persiapan adalah tahap undangan dari Mitra untuk rencana kegiatan (2) Tahap selanjutnya adalah rapat dan diskusi dengan tim untuk materi pembekalan bagi Relawan Pajak dan diskusi dengan mitra untuk teknis pelaksanaan sesuai harapan mitra. (3) Tahap Pelaksanaan bersifat luring dengan protokol Kesehatan yang ketat, antara lain wajib memakai masker, kondisi wajib pajak dan petugas sehat, jarak meja pelayanan yang berjauhan(4) Tahap evaluasi dan pembuatan Laporan Pertanggung Jawaban kepada LPPM dibuat setelah PKM selesai dilaksanakan (5) dan akan dipublikasikan dalam bentuk artikel pada saat acara Serina tahun 2021.

\section{HASIL DAN PEMBAHASAN}

Selama 4 hari pelayanan secara luring dapat dilayani sebanyak 30 wajib pajak dengan berbagai masalah dan bantuan yang dapat diberikan, antara lain, meminta E-Fin ke Kantor Pajak, me reset password, menghitung kurang bayar dan mengisi SPT serta mengirimnya secara daring. Kegiatan dilakukan secara luring/offline, di gedung Blok M-Kampus I Universitas Tarumanagara, berlangsung sejak 17-19 Maret dan 26 Maret 2021 dengan agenda sebagai berikut:

1.Membuat Pengumuman untuk eksternal dan internal melalui media yang tersedia.

2.Membuat Form pendaftaran dengan google form untuk antisipasi petugas yang akan melayani.

3.Menyiapkan perangkat laptop untuk keperluan pelayanan PKM ini.

Hasil kegiatan berupa aktivitas pelayanan dan asistensi bagi para wajib pajak yang mendaftar dan hadir, antara lain melayani konsultasi WP OP untuk kewajiban perpajakannya, meminta kembali E-Fin untuk WP OP yang lupa password DJP online nya, membantu melaporkan SPT para WP OP. Hal ini juga menjadi pengalaman bagi para mahasiswa Relawan Pajak, yaitu berinteraksi dengan para WP OP dan turut membantu pihak KPP. 
Berikut adalah foto-foto kegiatan selama kegiatan berlangsung:

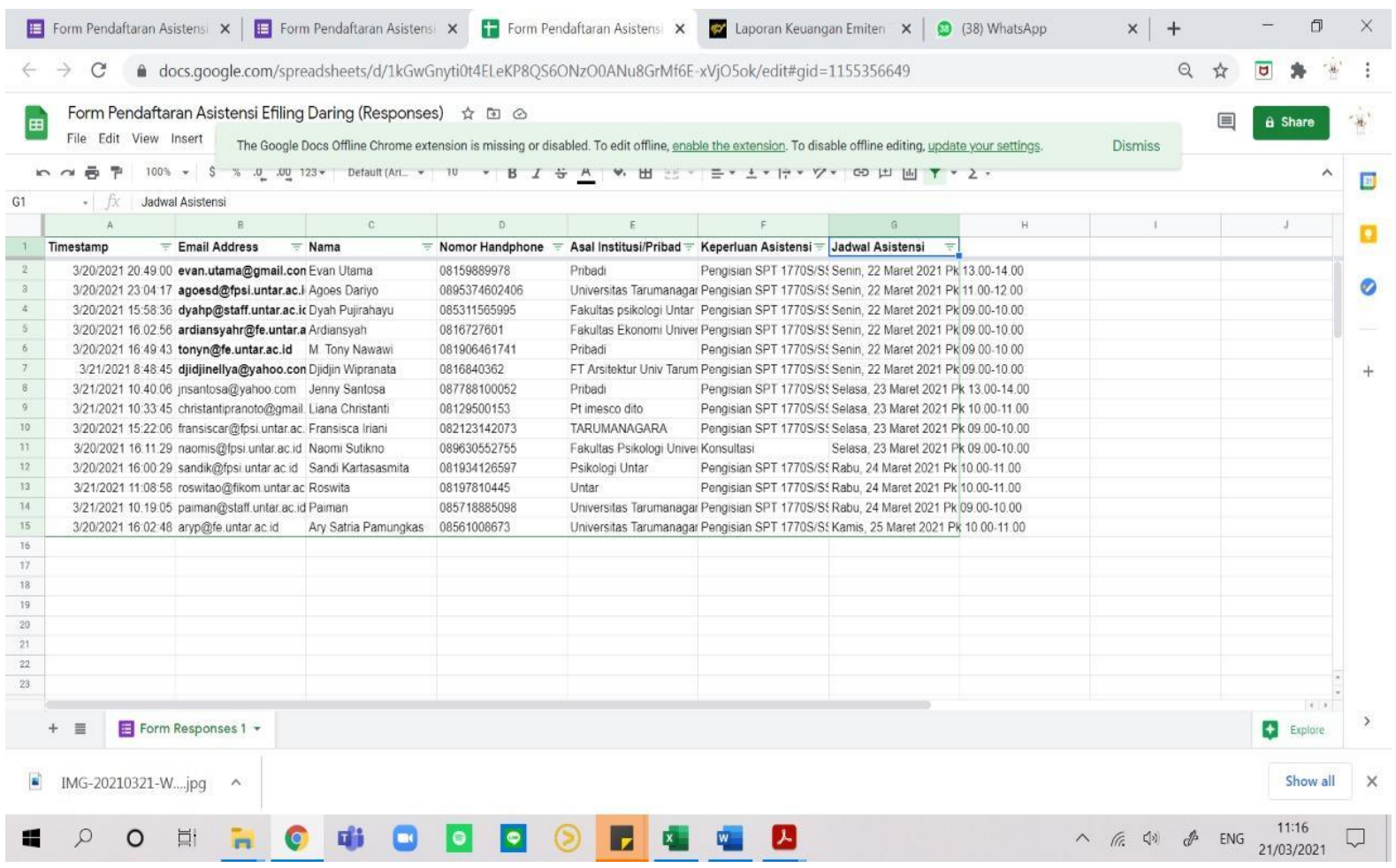

Gambar 1. Contoh pendaftaran hasil Google Form

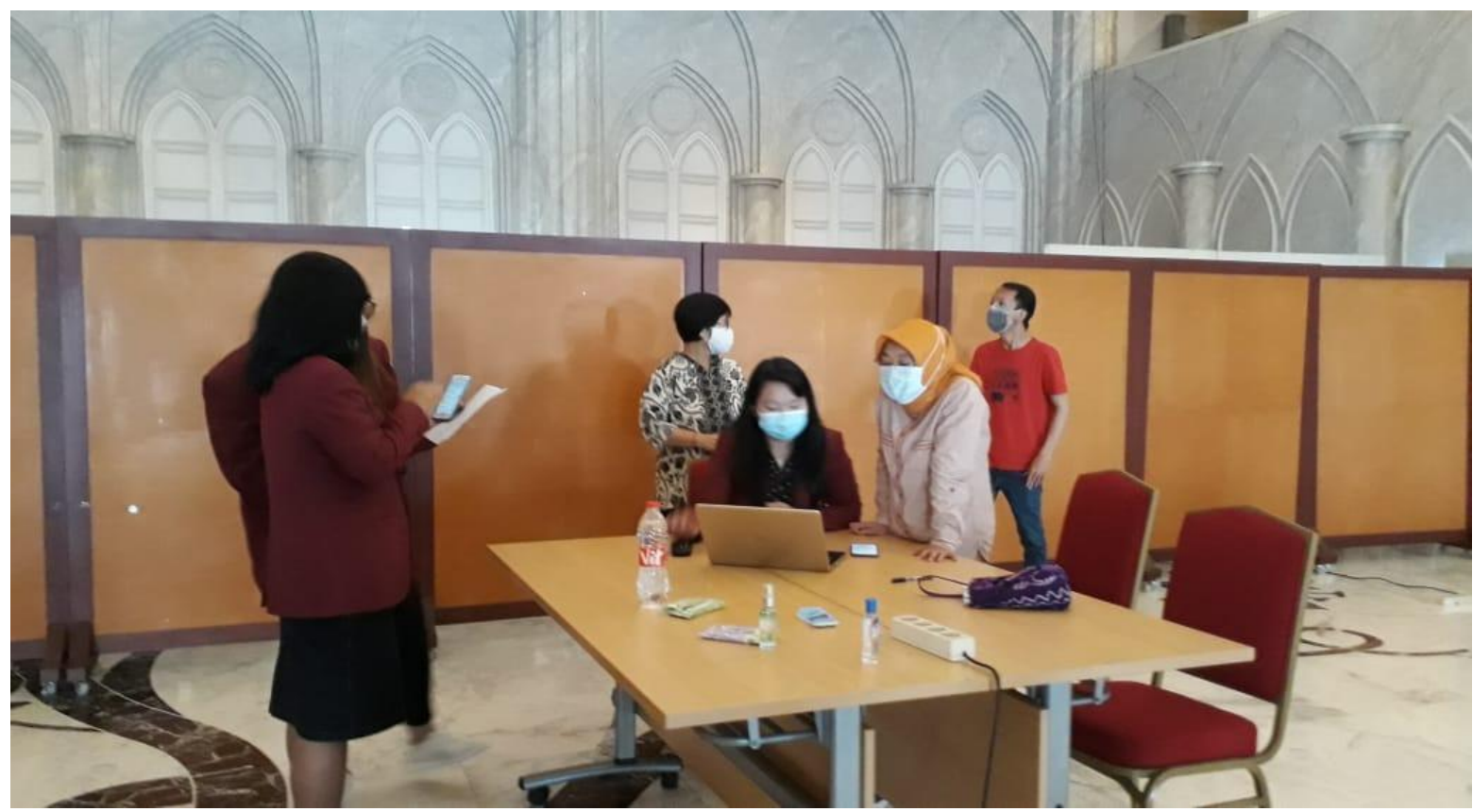

Gambar 2. Tim sedang melayani wajib pajak 


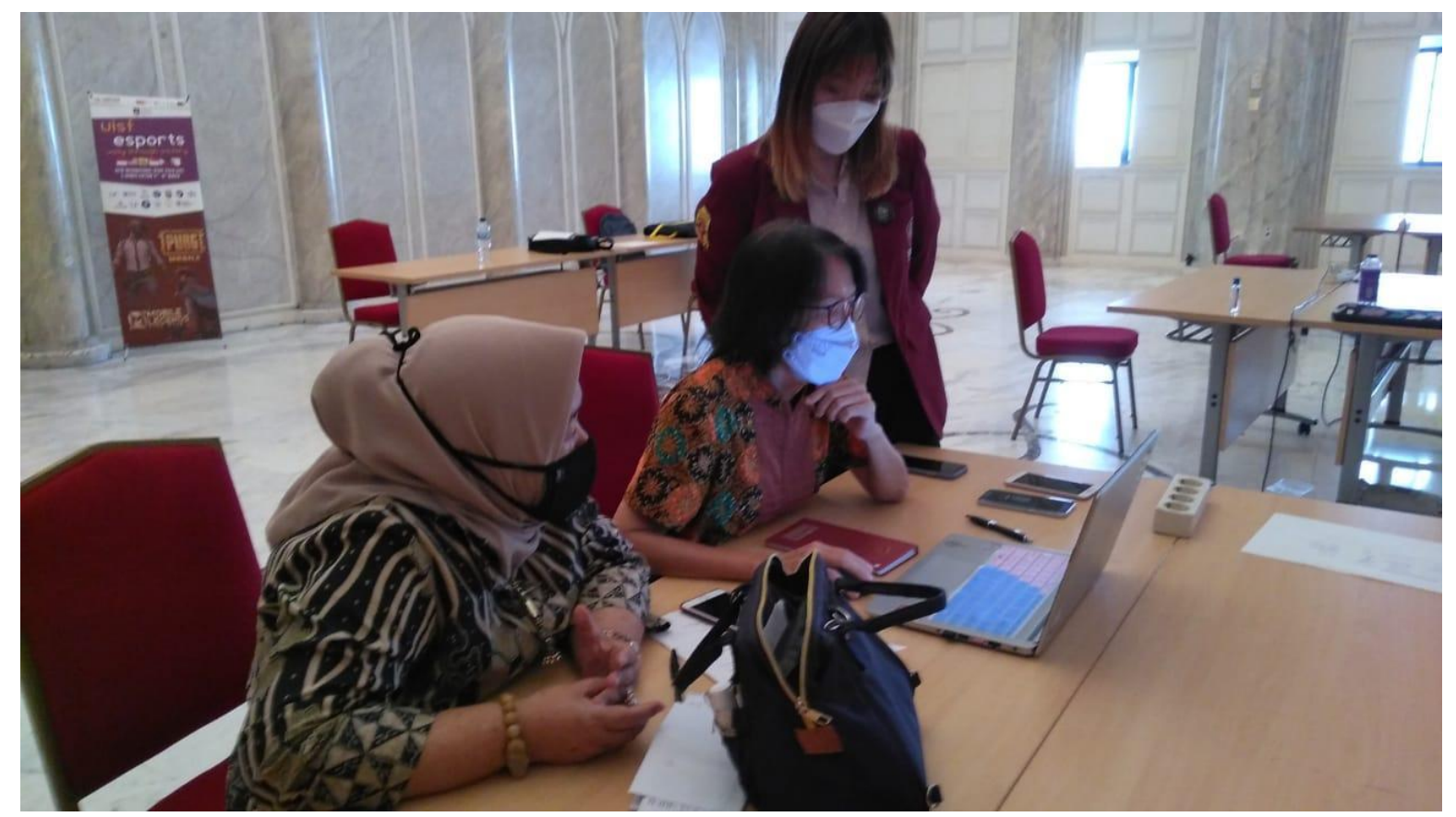

Gambar 3. Tim sedang melayani wajib pajak

\section{KESIMPULAN \\ Kesimpulan}

Kegiatan pelayanan dan asistensi pengisian SPT bagi Wajib Pajak Orang Pribadi melalui pertemuan luring sangat membantu para wajib pajak yang hadir dan dapat berjalan dengan cukup lancar. Para Wajib Pajak yang akan melaporakan SPT pribadinya ternyata sering lupa dengan password dan atau Efin nya, sehingga tim juga berusaha membantu. Para Mahasiswa Relawan Pajak dengan didampingi tim dosen terkait membantu menjelaskan pertanyaan maupun pengisin SPT dan meng unggahnya di djp online.

Walaupun tidak seramai yang diharapkan, kegiatan ini dapat dinilai cukup berhasil sebagai suatu kerjasama Perguruan Tinggi dengan Direktorat Jenderal Pajak dalam usaha pelayanan pihak KPP kepada Wajib Pajaknya, juga kerjasama dan kesempatan edukasi melalui para mahasiswa Relawan Pajak yang ikut dalam kegiatan.

\section{Saran}

Sebagai suatu jembatan antara dunia kampus dengan dunia usaha, maka kegiatan selanjutnya dapat tetap dilaksanakan, dengan persiapan yang lebih baik dari segi teknologi maupun penyebaran informasinya kepada para Wajib Pajak, agar mereka benar dapat terbantu dan mudah mengaksesnya.

\section{Ucapan Terima Kasih}

Terima Kasih kami ucapkan kepada pimpinan Universitas Tarumanagara khususnya Ketua LPPM dan Staf serta pimpinan Fakultas Ekonomi beserta staf dan Mitra PKM yaitu Direktorat Jenderal Pajak Kanwil Jakarta Barat III atas kepercayaan untuk membantu inklusi kesadaran pajak para wajib pajak dengan memberdayakan para Relawan Pajak dari Mahasiswa Untar serta Rekan Dosen dan para mahasiswa yang membantu terlaksananya PKM ini. 


\section{REFERENSI}

Devano, Sony dan Siti Kurnia Rahayu. 2006. Perpajakan Konsep, Teori dan Isu. Jakarta : Kencana Prenada Media Group.

Jatmiko, A.N. 2006. "Pengaruh Sikap Wajib Pajak pada Pelaksanaan Sanksi Denda, Pelayanan Fiskus dan Kesadaran Perpajakan terhadap Kepatuhan Wajib Pajak (Studi Empiris terhadap Wajib Pajak Orang Pribadi di Kota Semarang)”.Tesis Magister Akuntansi Program Pascasarjana Universitas Diponegoro.

Kementerian Sekretariat Negara RI; (2008); Undang-Undang Nomor 28 Tahun 2007 tentang Ketentuan Umum dan Tata Cara Perpajakan.

tentang Pajak Penghasilan. (2009); Undang-Undang Nomor 36 Tahun 2008

Lukman, dkk (2019). ; Minat Menjadi Relawan Pajak, Senapenmas Untar

Mardiasmo. 2016. Perpajakan Edisi Revisi, Penerbit Andi, Yogyakarta.

Resmi, Siti; (2018); Perpajakan Teori dan Kasus; Jakarta: Penerbit Salemba Empat.

Sugeng Wahono. 2012. Teori dan Aplikasi: Mengurus Pajak itu Mudah. Mojokerto: Gramedia Direct.

Susyanti, Jeni dan Dahlan, Ahmad; (2015); Perpajakan Untuk Praktisi dan Akademisi; Malang: Penerbit Empatdua Media.

Waluyo. (2011). Perpajakan Indonesia. Salemba Empat.

www.pajak.go.id 